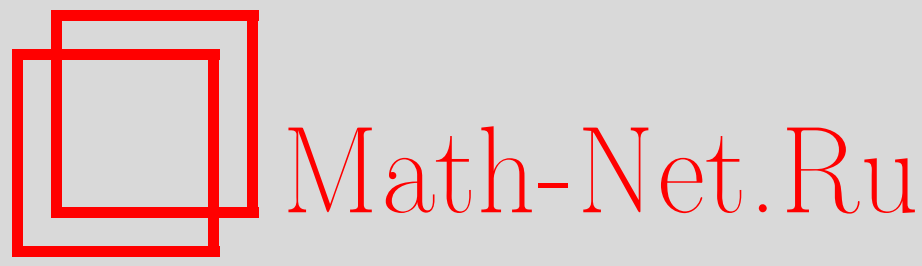

Нелинейная физика: теория и эксперимент. V, ТMФ, 2009, том 160, номер 1, 3

DOI: https://doi.org/10.4213/tmf6372

Использование Общероссийского математического портала Math-Net.Ru подразумевает, что вы прочитали и согласны с пользовательским соглашением http://www . mathnet.ru/rus/agreement

Параметры загрузки:

IP : 34.229 .108 .108

26 апреля 2023 г., 14:18:23

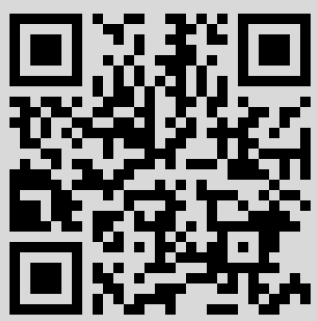




\section{НЕЛИНЕЙНАЯ ФИЗИКА: ТЕОРИЯ И ЭКСПЕРИМЕНТ. V}

В данном выпуске мы завершаем публикацию трудов конференции "Нелинейная физика: теория и эксперимент. V".

В т. 159, № 3 были опубликованы следующие доклады:

Абловиц М. Дж., Хот Т. С. Связанные нелинейные уравнения Шредингера для соприкасающихся жидкостей со свободной поверхностью

Арджери М., Бароне В., Де Лилло С., Лупо Дж., Соммакал М. Существование минимумов энергии для упругих тонких стержней в статических спиральных конфигурациях

Беккариа М., Форини В. КХД-подобные свойства аномальных размерностей в $\mathcal{N}=4$ суперсимметричной теории Янга-Миллса

Бойти М., Пемпинелли Ф., Погребков А. К., Принари Б. Построение расширенной резольвенты оператора теплопроводности с помощью сплетающих преобразований

Катиньо Ф., Беккариа М. Предел больших спинов для операторов твиста в $\mathcal{N}=4$ суперсимметричной теории Янга-Миллса

Чан Цзень-Ху, Чэнь Юй-Тун. Решения вещественной бездисперсионной иерархии Веселова-Новикова

Конт Р., Грюндланд А.М., Юард. Решения уравнений изэнтропийного течения жидкости в виде римановых инвариантов

Эстевес П. Г. Преобразования двойственности для спектральной задачи в размерности $2+1$

Эйлер М., Эйлер Н., Лундберг С. Об обратных преобразованиях Беклунда для автономных эволюционных уравнений

Гандариас М. Л. Нелокальные симметрии и редукции для некоторых обыкновенных дифференциальных уравнений

Герджиков В. С., Костов Н. А., Вылчев Т. И. Многокомпонентные нелинейные уравнения Шредингера с постоянными граничными условиями

Гилсон К. Р., Ниммо Дж. Дж. К., Суман К. М. Матричные решения некоммутативного уравнения КП и некоммутативного уравнения мКП

Кауп Д. Дж. Интегрируемые системы и квадраты собственных функций

Хуснутдинова К.Р., Самсонов А. М., Захаров А.С. Нелинейные длинноволновые модели для слоистых волноводов с неидеальным контактом

Киселев А. В., Хуссен В. Виртуальные многосолитонные решения в форме Хироты $N=2$ суперсимметричных уравнений Кортевега-де Фриза

Конопельченко Б. Г. Непрерывно-дискретные интегрируемые уравнения и преобразования Дарбу как деформации ассоциативных алгебр

Новокшенов В. Ю. Аппроксимации Паде для трансцендентов Пенлеве I и II

Окстоби О.Ф., Барашенков И. В. Асимптотическое разложение для раскачивающегося кинка

Земляная Е. В., Алексеева Н. В. Осциллирующие солитоны в нелинейном уравнении Шредингера с диссипацией и накачкой 